\title{
The Research of the Sergeant Education Practice Teaching Personnel Training
}

\author{
Xiuwen $\mathrm{Hu}^{1, \mathrm{a}}$, Qiang $\mathrm{Li}^{2, \mathrm{~b}}$ and $\mathrm{Yun} \mathrm{Li}^{3, \mathrm{c}}$ \\ 1, 2, 3 chang chun engineering technology college, Changchun, 130117, China \\ a294244476@qq.com, b165007605@qq.com, '9429208@qq.com
}

Keywords: Sergeant education; Practice teaching; Personnel training; Research

\begin{abstract}
Based on the analysis of our army units and NCO NCO professional education practical teaching on the basis of the status quo, existing in our NCO academies practical teaching problems, put forward the idea of reforming the practical teaching system, and puts forward the practical teaching reform of specific measures. Highlight the professional characteristics, the construction of practical teaching content system. Expand the way of thinking, innovative practical teaching mode. Strengthen the construction and improve the practical teaching guarantee system. Perfect the mechanism, train and develop the double qualified teachers. Focus on management, construction management skill evaluation system.
\end{abstract}

\section{Introduction}

Sergeant is the direct operators, high-tech weapons and equipment management and maintenance, not only to master the skills, have solid professional foundation, but also has rich management experience and the ability of training. Practice teaching is to enable students to deepen the understanding of specialized theories, including occupation skills and occupation moral ability positions, and has the ability of self-development, in order to fully complete the task of teaching, a kind of practice of the realization of the goal of training. Practice teaching is an important part of the education in the teaching process, is of great significance to raise petty officers' operation ability and creative spirit[1-3].

\section{Analysis of the Status Quo of College Practical Teaching of Our Military Officer}

Practical Teaching Situation. Since 1986, I open the first army officer school, Sergeant education came into being. In the traction Sergeant education development goals under the various colleges and universities are constantly strengthening practice, strengthen practical teaching, improving the practical teaching system. Some colleges and universities even break the traditional cultural basic courses, professional basic courses, professional courses three teaching mode, the practice of teaching throughout the whole process of teaching. In the practical teaching mode and method also has some breakthroughs, such as: take the sergeant teaching mode of " $2+1$ " food academy cadet, two years ago, after studying the theory of knowledge in Colleges and universities, last year internship in naval army corresponding professional positions, to accept the training of troops, learning skills; generally take a case seminar style teaching method; teaching security conditions continue to improve, provide a guarantee for the development of practical teaching. But under the influence of traditional education, NCO academies exists widely in the emphasis on theory teaching, ignoring practical teaching: pay attention to classroom lectures, ignoring the field practice teaching; focus on test scores, ignoring the ability[4,5].

The Main Problems of Practical Teaching. The content of teaching is not strong. In recent years, the school conducted a great reform of the education content, the discipline and specialty of large adjustment, integration, eliminated a large number of obsolete teaching content, some new emerging discipline, the teaching reform in teaching content as the center has achieved remarkable results. But due to various factors, the design of teaching content of $\mathrm{NCO}$ academies is lagging behind, the army of the practical needs of the construction of the slow response, the renewal of the teaching content is difficult to further the development of the situation; many military operations 
and training course content and actual needs serious gap caused by conventional did not learn, learn not work; too much emphasis on the integrity of academic theory, relevance and flexibility of teaching content ignored.

Curriculum structure is not reasonable. At present, our military academies have unreasonable curriculum structure, professional practice class accounted for a small proportion of the practice, weak foundation, practice facilities, practice method is simple, some practice course is not an independent course and other issues, this situation leads to heavy and light academic practical, theoretical and practical light, theory and Practice, learning and with some disconnection. The one hand, that use, on the other hand does not apply, this situation will not be able to adapt to favour one more than another Sergeant education development needs.

Practical teaching mode is single. The teaching practice of sergeant colleges is mainly completed the following three training: first, test and verification of training. Such as circuit testing, mechanical experiments, students complete the syllabus of the content of the study, master the basic principles or methods, test and verify the correctness of the knowledge learned, and even some of them is only a demonstration test. Second, the concept of basic training. As graduation practice, students in contact with the actual equipment, enhance the concept, deepen the impression, or find problems in the process of treatment is similar to that of I, so as to lay the foundation for further study and design. Third, virtual, imitative training. Such as curriculum design, graduation design, equipment maintenance practice, teachers often require students to virtual design according to the principle and method of Teaching Professor, referring to previous examples of equipment fault troubleshooting, or a complete equipment operation training and related job responsibilities. This traditional practice teaching mode is not conducive to the cultivation of students' innovation ability, it is difficult to solve the problems encountered in practical work. Although some colleges and universities have explored some new ways in the exploration of the practical teaching mode, most of them still remain in the stage of research and exploration.

The practical ability of teachers should be further strengthened. The sergeant training faculty status and high-quality personnel requirements there is still a gap. First, the basic theory can not meet the needs of teaching. In the rapid development of science and technology, knowledge update has intensified the situation, existence of aging teacher knowledge, much of the new technology and new equipment to understand the knowledge, in teaching practice can not effectively put these new technologies and new knowledge to the personnel. Two is the professional skills, professional skills and teaching needs more prominent contradictions. Not only the basic class teachers generally practical ability is not strong, is also the problem of professional teachers. This situation is not only focus on the influence of knowledge theory of traditional education concepts, but also by the staff sergeant sources determined. In recent years, the army, young teachers colleges lack of military practice in their life, do not understand the forces, not familiar with the officers, not enough grasp of new equipment, new tactics, practice ability is weak, in the process of teaching, more emphasis on imparting knowledge, but not for non commissioned officers of the post requirement, effective training comprehensive quality and practice ability of students.

College education and army training is not effective combination.It is an effective measure to improve the education and training benefits of our army, especially to improve the ability of the students. But because membership is not smooth, work center, different responsibilities is unknown, lack of coordination mechanisms, the interface problem of school education and military training to ask is not well resolved, and has become a bottleneck in the education training quality.

Practical teaching is not linked to the soldier's skill appraisal work.To promote the development of occupation skill appraisal work forces and specific professional college graduate cadet, strengthen become an urgent and important task of the construction of personnel ranks. At present, the content of teaching is only focused on the needs of teaching, especially the content of practical teaching $[6,7]$.

\section{Sergeant education practice teaching reform and innovation}

Establish Practical Teaching Reform Ideas. Teaching reform must focus on the central task of 
the army and attach importance to the cultivation of practical ability. Practical teaching is an independent teaching, comprehensive application of which is different with the traditional teaching methods, but according to different training level, the new teaching mode of teaching objective, teaching content, method and means of integration. The students in Colleges and universities acquisition of book knowledge depends mainly on theory teaching, mainly rely on the practical teaching experience and teaching practice to obtain indirectly, to achieve the combination of the two is also applicable to sergeant education. Therefore, the practical teaching in the school running characteristics of sergeant education in the new overall consideration, system planning. At present, Sergeant education practical teaching are unclear thinking, unreasonable system problems, should focus on the central task force, close to the actual, practical teaching ideas for broadening, strengthen practical teaching, accelerate practical teaching into the "classroom" speed. The author believes that the current establishment of the basic ideas of sergeant education practice teaching is the practical teaching to expand their horizons, to set up the new teaching concept, the practical teaching reform has been a breakthrough. We must focus on the central task, close to the actual troops, adhere to the combination of theory and practice, to meet the needs of the post, to highlight the case of teaching and training students comprehensive operation, problem analysis skills and organizational management in practice[8].

The principles of carrying out practical teaching. Principle of reductionism. It refers to the practice teaching should be carried out under the guidance of the theory, through the practice of teaching so that the theory of sublimation, to achieve the combination of theory and practice. Through practice, cognition, practice again and understanding repeatedly, in order to obtain a rational knowledge, this is the understanding of the basic law of the development of the theory of the principle of reduction is the application of this rule in practice teaching.

Strictly from the principle of starting from the actual needs. It refers to the practice of teaching, especially the teaching of military technology and tactics, to maximize the close combat, meet the actual needs, do what the actual need of teaching practice teach what, what to learn. Really teach for war, learning for war, research for the war, all to win.

Principles of independent practice. This principle emphasizes the independent operation, independent operation, independent exploration and independent problem solving. Practice teaching is a very active teaching activities, in dealing with the problem, let the students to fully express their different views, put forward a variety of solutions, let us compare, can give full play to their talents, but also can benefit by mutual discussion, each other, enrich and improve themselves.

Construction of Scientific and Reasonable Practical Teaching System. Prominent professional characteristics, the construction of practical teaching content system. To develop training programs to highlight the cultivation of practical ability. The teaching practice of sergeant education, as a kind of planning practice, practice ability must be placed in a prominent position of talent, the practical teaching contents and links into the teaching plan and syllabus and training plan, become the organization of faculty teaching basis. In the development of personnel training programs, to highlight the enhancement of thinking training analysis and research ability, enhance the ability of planning to participate in military training, to enhance the ability of organization and command of the scene simulation and training, so that students in the plan and improve the quality of teaching objectives, to exercise. In the design of practical teaching content, should according to the requirements of the overall goal of practice teaching arrangement to the practice teaching content complete, according to the specific practice of teaching objectives and requirements reasonable arrangements for the specific content of each implementation or every practice; both teaching goals are students learn the target. Optimizing course system. Starting from the curriculum design to optimize the whole set of sergeant education courses. In the curriculum design, we should establish the curriculum standards on the basis of the needs of the post, refine the talent training objectives, decompose, and then integrate into the curriculum, to achieve the full convergence of curriculum and talent training objectives. In the development of teaching plan, it is necessary to increase the practicality of the curriculum, the specific provisions of the practical teaching time, so that the limited teaching time to maximize the effectiveness of teaching. The teaching contents 
should be optimized in some practical courses, the basic theory and application of theory and case study, want to work the content of organic integration, the formation of a rational structure of the teaching content system. Constructing the teaching material system suitable for practical teaching. The sergeant education practice teaching requires certain theoretical learning as the premise, to ensure that the analysis of the problem of students from a scientific perspective, and uses relevant theory and experience to solve problems. Practical teaching should be carried out under the guidance of the theory, through the practice of teaching so that the theory of sublimation, to achieve the combination of theory and practice. In the course design, the content of the theory teaching and the practical teaching should be integrated into the actual operation and maintenance ability and organization ability. Therefore, it is necessary to construct the corresponding teaching material system according to the characteristics of practical teaching[9].

Expands the train of thought, the innovation practice teaching pattern. Practical teaching in the classroom, in the local organization, can also perform their duties in the organization under the condition of. In view of the lack of practical teaching mode in our army, the reform of practical teaching should be carried out, and the mode of development should be carried out in many ways and channels. One is the organization of teaching. As a political theory course, by visiting the bases for patriotic education, grassroots advanced units and make the students through the direct observation of the actual situation, to obtain specific perceptual knowledge and real and vivid visual impression, deepen thinking, deepen the theory; such as post class, organize students to practice base practice or on behalf of military exercise, both be familiar with the equipment, to strengthen the understanding of the theory, but also enhance the ability of practice. The two is the success of the grass-roots units, after research and analysis, the introduction of teaching. Such as management, law, training and other courses, according to the teaching content to choose a series of cases, the theoretical analysis, to find out the successful experience or failure lessons. The three is to work. I want to work with the enemy situation, both sides attempt to combat and combat development scenario as the basis, a method of organization and induction training. As a professional command, tactical comprehensive training courses, to provide customized according to different situations, the series work consists of multi form and multi subject, multi situation, guide the students to learn to use the theory of creative thinking and deduction in accordance with the army's combat program. Four is the use of modern teaching facilities and high-tech means, the organization of simulation training teaching. The main work is to simulate the actual work and combat the actual situation of the simulation teaching. To improve the students' ability to apply theoretical knowledge to solve practical problems through simulation teaching, so as to achieve the effect of similar combat. The traditional "play" and "practice", through the pre setting of the situation, so that students get exercise, so as to achieve the purpose of teaching. In order to better reflect the reality of confrontation, stimulate the enthusiasm, initiative and creativity of students, students should be guided in the "play" and "practice" in the "resistance" and "research"". Through the actual test, the ability and quality of the students have been further improved.

Strengthen the construction and improve the practical teaching guarantee system. Actively develop practical teaching training equipment. To improve the sustainable development of practical teaching, and to focus on research and development. Forward-looking and advanced training equipment. First of all, it is necessary to improve the generality of the system components, and the training equipment should have certain expansibility on the basis of the teaching and training functions. Secondly, we should ensure the advanced nature of the technology. The rapid development of high and new technology has provided a good technical support for the construction of training equipment, the development of training equipment must stand in the forefront of the development of science and technology, and strive to adopt the most advanced, most mature technology. Pay attention to the whole training equipment system, give full play to the effectiveness of training. Focus on the development and development of virtual simulator. In view of the need of information warfare simulation system, build the skills necessary for implementation of nco. The levels of security platform in the computer network, to achieve accurate implementation of network security management, teaching skills, teaching skills to establish implementation of security 
information system, establish common fault analysis database skill teaching, and strive to do a good job of sharing work skill teaching data resources, construct integrated information security system implementation skill teaching, establish based on the database platform, play the biggest role of resource security[10].

Improve the mechanism to cultivate the "Double Teachers" team. Need a number of practical teaching can not only teach with solid professional theoretical knowledge, solve the practical problems in the construction of the army, and the rich practical experience and skill to guide students in the actual operation of the teacher ("double teacher" teacher). To train and bring up a team of "Double Teachers", we should reform the closed and passive training mode, improve the ability and quality of teachers as the center, widen the channels, and adopt various methods to carry out the open cultivation.

Focus on management, construction management skill evaluation system. First of all, clear management skill evaluation target. Understand each skill repeated evaluation objectives and to achieve this goal should pay attention to specific issues, familiar with the operation skill evaluation scheme. Secondly, analysis and evaluation of factors of skill. According to the operation skill for the purpose of evaluation, to collect relevant information and data, a comprehensive analysis of the various elements of the teaching system, the main factors to seize teaching security. Third, determine the evaluation index system of management skill. The index is a specific sign of implementation skills. For the implementation of skill evaluation system, must establish a unified scale control and can measure, namely the implementation skill evaluation index system. Fourth, formulate implementation skills evaluation structure and evaluation criterion. In the implementation of the skills assessment process, must follow the scientific evaluation of the combination of qualitative and quantitative methods, the qualitative quantitative description index to quantify. Fifth, determine the evaluation method of skill. According to the system goal and the system analysis result, the expense, the effect determined the appraisal method. In the implementation of skill evaluation based on the use of models and data, from the view of system, comprehensive analysis, further scientific and objective of teaching guarantee system for evaluation of military academies.

\section{Summary}

How to carry out the education, has a decisive influence on the working ability and the role of sergeant. Sergeant post practical requirements of sergeant education pay more attention to practical teaching, and vigorously carry out practical teaching. At present our NCO academies practice teaching has not been fully aware of the practical teaching system is not perfect, affect the sergeants' competency. Therefore, the author believes that the sergeant education must attach great importance to the practical teaching, the practical teaching of college teaching work into the overall planning, and reform the current practice of teaching is not reasonable, to construct a scientific and reasonable system of practice teaching.

\section{References}

[1] L.Q. Cao, An Chen, Fan Wang. To explore the new training mode of the cadet. China Science and technology,2015(15). (In Chinese)

[2] Z.M. Liu,Z.L. Zhou, R.X.Li. Thinking on the teaching mode of education practice of officers. documentation .2016, 6(2).(In Chinese)

[3] W.J.Zhang. Research on the education idea of people-oriented and the application in the sergeant training, International Conference on Applied Social Science Research,2013.(In Chinese)

[4] John F. McNeirney. Regimental Command Sergeant Major, Military police, 2013, (Fall).

[5] Jeffrey Butler. Regimental Command Sergeant Major. Military police. 2008, 0(spring). 
[6] H.L.Cheng,Y.J.Wen,Y.J.Yao.The teaching content improvement within the hierarchical practical teaching system of accounting profession in independent colleges - Taking the accounting profession of Jiangcheng College, China University of Geosciences as an example.

[7] International conference on economic management and trade cooperation: EMTC 2014, Xi an, China, 12-13 April 2014.

[8] S.Zhang,Y.J.Liu.The Application of "Practical Training Teaching Project" in the Teaching of Art Design.2nd International conference on education, management and social science: ICEMSS 2014, Shanghai, China, 21-22 August 2014.(In Chinese)

[9] Vaughan, Brett; Macfarlane, Chris.Perceived teaching quality between near-peer and academic tutors in an osteopathic practical skills class. International journal of osteopathic medicine: IJOM,2015, 18(3)..

[10] Y.L.Liu. Follow the teaching rules to establish practical teaching goal. The young writer, 2016(19). (In Chinese) 